skasuvannya mizhderzhavnoho standartu [On the adoption of national standards, the adoption of amendments to the national standard, the abolition of the interstate standard]: nakaz Derzhavnoho pidpryyemstva «Ukrayins'kyy naukovo-doslidnyy i navchal'nyy tsentr problem standartyzatsiyi, sertyfikatsiyi ta yakosti» vid 17 kvitnya 2019 r. № 95. URL: http://uas.org.ua. [in Ukr.]

14. Pro zatverdzhennya Instruktsiyi pro pryznachennya ta provedennya sudovykh ekspertyz ta eks-pertnykh doslidzhen' ta Naukovo-metodychnykh rekomendatsiy z pytan' pidhotovky ta pryznachennya sudovykh ekspertyz ta ekspertnykh doslidzhen' [On approval of the Instruction on appointment and conduct of forensic examinations and expert research and Scientific and methodological recommendations on preparation and appointment of forensic examinations and expert research]: nakaz Ministerstva yustytsiyi Ukrayiny vid 08.10.1998 № 53/5 (u redaktsiyi nakazu Ministerstva yustytsiyi Ukrayiny vid 26.12.2012 № 1950/5). URL: https://zakon.rada.gov.ua/laws/show/z0705-98. [in Ukr.]

\title{
SUMMARY
}

Petro M. Baranov, Roman S. Kirin. Features of forensic gemological examination of Pearls and Amber. The article discusses the features of the forensic examination of organogenic origin gemstones - amber and pearls, which are in the in the same group of organogenic origin gemstones, have different conditions of origin and therefore they formed different markets on the complexity and ambiguity.

Unlike the legislation of importing countries, where cultured pearls are not a precious stone, in Ukraine this stone is included in the scope of regulation of gemological legislation and the requirements of which to provide for control by the Accounts Chamber, the National Bank of Ukraine, and the Ministry of Finance of Ukraine. At the same time the state regulatory requirements for the quality of pearls are not, just as there are no price lists for prices. Consequently, the legal relations of cultured pearls in the domestic market are practically unsettled, and this problem must be solved taking into account the foreign experience of market interstate relations.

From the point of view of the forensic examination, the pearl is quite easy to identify, which allows you the problems to competently and quickly to solve facing the forensic expert. The certificates of origin and quality, which are usually attached when moving a stone across the border facilitate expert production. Amber is considered as the only gem in Ukraine and the extraction of which may be illegal. This leads to the illegal sale of raw materials, manufacturing of products, certification. Therefore, forensic gemological examination has complex tasks in determining the quality of raw materials, origin, pricing policy, certification. pearls.

Keywords: forensic gemological examination, pearls, amber, expert tasks, production, cultured

УдК $343.01 ; 343.9 .01$

DOI: $10.31733 / 2078-3566-2020-2-235-241$

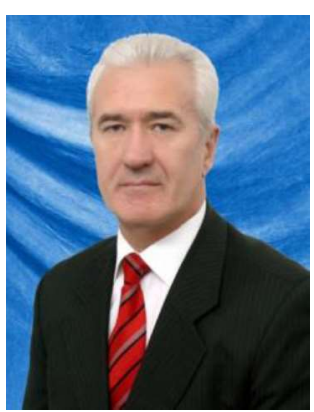

Олександр САІНЧИН ${ }^{\odot}$

доктор юридичних наук, професор (Херсонський державний університет)

\section{ТЕОРІЯ ТА ПРАКТИКА КРИМІНАЛІСТИКИ ЗА КОРДОНОМ}

У статті продовжено дослідження проблем теорії та історії розвитку криміналістики у США та деяких європейських країнах, зокрема в Англії. У цілому метою цього аналізу є встановити, яким чином розвивається криміналістика за межами нашої держави, із якими проблемами вона стикається, а головне - дійти до висновку про необхідність перебудови (або достатність) системи криміналістичних методів та експертних досліджень.

Проведене дослідження стосується виключно теорії та історії розбудови наукових пізнань у зарубіжній криміналістиці, виявлення позитивних рис ії сучасного розвитку та екстраполяції на умови розвитку нашої науки, яка слугує певним інструментарієм у розслідуванні злочинів та встановленні осіб, які їх учинили.

У подальшому заплановано започаткувати дискусію в середовищі науковців та практичних працівників, задіяних у розслідуванні злочинів, про можливу імплементацію сучасних досягнень наших колег-криміналістів за кордоном.

Ключові слова: криміналістика, історія криміналістики, криміналістика за кордоном, криміналістика в деяких крайнах Європи, у США, криміналістика як наука та прикладна галузь права.

(C) Саінчин O.C., 2020

ORCID iD : https://orcid.org/0000-0003-0243-7524

sainshin@ukr.net 
Постановка проблеми. У другій половині XIX століття, у період різкого загострення соціального антагонізму та швидкого зростання злочинності в країнах Свропи, зазначені процеси зумовили необхідність створення й виділення в самостійну дисципліну науки, яка служила б певним інструментарієм (зброєю) у протидії злочинності та розкритті скоєних злочинів.

Науку назвали криміналістика (від лат. criminalis - злочинний, який стосується злочину), яку в цілому визначили як прикладну юридичну науку, що досліджує закономірності готування, скоєння та розкриття злочинів, виникнення й існування його слідів, збирання, дослідження, оцінки й використання доказів, а також розробляє систему заснованих на пізнанні цих закономірностей спеціальних прийомів, методів і засобів, які застосовують у ході попереднього розслідування для попередження, розкриття й розслідування злочинів, а також під час розгляду кримінальних справ у судах.

Метою статті є дослідження проблем теорії та історії розвитку криміналістики у США та деяких країнах Європи.

Виклад основного матеріалу. Засновником криміналістики як науки вважають австрійського судового слідчого Ганса Гросса, який одним із перших загострив увагу на речових доказах у розкритті злочинів, на використанні науково-технічних засобів і методів природничих наук для їх виявлення й дослідження. Написаний ним «Порадник для судових слідчих, чинів загальної та жандармської поліції» пізніше став називатися «Порадником для судових слідчих як системи криміналістики» (1892). Криміналісти Європи, Росії та України дотепер вважають цей підручник першим та основним, що дав початок криміналістиці як науковій та практичній дисципліні.

Становлення криміналістики як наукової дисципліни у Свропі відбувається з цього періоду, але в Китаї з 1248 р. відома книга «Си-уань-юй», у якій оприлюднено медичні знання для встановлення розбіжностей між насильницьким утопленням та удушенням і встановлення особи за відбитками пальців $[1,2,3]$.

У державах Західної Свропи криміналістика виникла й розвивалася перш за все як прикладна, технічна дисципліна, яка узагальнює діяльність поліції, не регламентована законом, що знайшло відображення в працях А. Бертільйона, Е. Локара, Р. А. Рейсса. До числа перших у Європі належать Німеччина й Австрія. Австрія, як уже було зазначено вище, $є$ «колискою» криміналістики, оскільки після досліджень Г. Гросса ця особлива галузь наукового знання отримала подальший успішний розвиток у роботах Ф. Айхберга, Г. Когеля, А. Ліхема, В. Польцера, К. Вальхерена й ін. [4].

Історію становлення й розвитку криміналістики в Німеччині можна розділити на три періоди: із моменту зародження й до закінчення Другої світової війни; років одночасного існування Федеративної Республіки Німеччини й Німецької Демократичної Республіки; періоду після їх об'єднання.

Узагалі витоки криміналістики в Німеччині були закладені ще до робіт Г. Гросса, оскільки перші наукові праці німецькою мовою, присвячені організації поліцейської діяльності щодо розкриття злочинів, видавали тут і раніше. Прикладом цього можуть служити роботи К. І. А. Міттермаєра, Г. Циммерманна, Л. фон Ягеманна та інших авторів першої половини XIX ст. Сучасні німецькі дослідники пов'язують цей процес із більш ранніми роботами $з$ кримінального права, судової медицини, судової статистики й загальним розвитком наукового знання [5].

Разом із тим найактивніше становлення криміналістики в Німеччині почалося лише в кінці XIX - на початку XX ст., тобто одночасно з таким же процесом в Австрії. Про це переконливо свідчать роботи Р. Хейнделя, Х. Яргензона, Ц. Лейбіга, Е. Локара, Г. Шнейкерта та інших авторів [6, 7].

Значний внесок у криміналістику зробили вчені й практики Німецької Демократичної Республіки. Відповідно до особливостей побудови правоохоронної системи НДР, уже в перші роки ії існування виявлення та викриття осіб, які вчинили злочини, здійснювали спеціальні комісії, у складі яких були й фахівці в галузі криміналістики, що проводили дослідження речових доказів. У 1952 р. в НДР було створено Інститут криміналістичної (кримінальної) техніки, до обов'язків якого входило проведення криміналістичних експертиз. Крім цього, криміналістичні експертизи проводили в 15 окружних науково-технічних відділах Управління народної поліції Німецької Демократичної Республіки та в секції криміналістики Берлінського державного університету імені Гумбольдта.

Одночасно з практичним аспектом зміцнення криміналістики в НДР активно розвивалися й криміналістичні наукові знання. Уже в 1954 р. Б. Гертіг і Р. Шедліх підготу- 
вали й видали «Підручник для криміналістів». У 1978 р. за редакцією й безпосередньою участю професора Є. Штельцера було видано підручник «Соціалістична криміналістика», а в 1983 р. Х. Маєр, К. Вольф і Ю. Чекалла опублікували «Підручник криміналістики для поліції», що складається з трьох частин: 1) криміналістика як наукова дисципліна; 2) система комунікацій та інформації в органах поліції; 3) класифікація злочинців [8,9].

Цілий ряд грунтовних статей та інших наукових відомостей були опубліковані в журналах «Форум криміналістики» та «Криміналістика і судові науки». У цьому сенсі важлива робота відомого українського вченого, доктора юридичних наук, професора I. В. Постики - дисертація на тему «Основні проблеми криміналістичної науки, розкриття й розслідування злочинів у східноєвропейських країнах», у якій досліджено проблеми криміналістики романо-германської групи країн Свропи [10].

Після об'єднання ФРН і НДР відбулися істотні зміни як у німецькій правоохоронній системі, так і в розвитку правознавства, у тому числі криміналістики. Зараз криміналістика залишається в Німеччині однією із загальновизнаних наук, але оцінка ії змісту та значення починає змінюватися.

Свідченням цього є окремі статті, що містять критичні відгуки про колишню систему викладання криміналістики, а також новий двотомний підручник «Криміналістична компетенція», виданий за загальною редакцією Р. Р. Ягера. У підготовці підручника взяли участь понад 25 авторів, у тому числі відповідальні практичні працівники німецької поліції, фахівці в галузі криміналістичної техніки та такі відомі вчені, як професори А. Форкер, Р. Ніссе, 3.-М. Ріхтер, Ю. Шток, В. Треншель та ін. [11].

Крім іншого, у підручнику подано й розгорнуте визначення криміналістики. Із точки зору його авторів, «криміналістика - це наука про стратегію й методику розкриття злочинів і викриття злочинців за допомогою оперативних, тактичних і технічних способів боротьби зі злочинністю» [12]. На наш погляд, коротко й науково недосконало, але для слухачів чітко й зрозуміло.

Таким чином, дійсно, у наш час у Німеччині криміналістику розглядають як важливу галузь наукового знання, досягнення якої мали 6 забезпечити ефективне попередження, розкриття та розслідування злочинів. Попри це зміст сучасної німецької криміналістики не має науково обгрунтованої системи, відмінності від кримінології й теорії оперативно-розшукової діяльності та чіткого певного об'єкта й предмета дослідження, про що свідчать також інші наукові роботи останніх років, присвячені проблемам криміналістичного наукового знання. Закони розвитку науки рано чи пізно, але потребуватимуть дослідження цих проблем, і одним із джерел їх вирішення може бути загальна теорія вітчизняної криміналістики [13].

Слід зупинитися також на розвитку криміналістики у США, де на сьогодні сформувалася система розслідування злочинів. Хоча вона й належить до загальної англосаксонської системи кримінального судочинства, проте має багато особливостей, які полягають у системі органів, наділених правом попереднього слідства й дізнання щодо явних злочинів, а також у формі та змісті кримінально-процесуальної діяльності.

Органи розслідування, або, як їх називають у США, органи, що застосовують право, поділяються на дві групи: 1) позбавлені права зобов'язувати свідків з'являтися на виклик і давати показання і 2) наділені таким правом. До перших належать поліція та прокуратура. До других - коронер, суддя, велике журі, а також відповідні урядові органи міністерств юстиції, фінансів, праці, охорони здоров'я, освіти й соціального забезпечення, сільського господарства, торгівлі, внутрішніх справ, сухопутних сил армії, військовоморського флоту, військово-повітряних сил, оборони, державного департаменту й поштового відомства.

Поряд із різноманіттям самих правозастосовних органів, кожен із них у свою чергу створює особливі слідчі структури. Наприклад, у Міністерстві юстиції США правом розслідування наділені: Федеральне бюро розслідування (ФБР), маршали США, Служба імміграції та натуралізації; у Міністерстві фінансів - Берегова охорона, Секретна служба, Бюро з наркотиків, Розвідка, Відділ податків на тютюнові та алкогольні вироби, Інспекція й Митна служба; у Міністерстві внутрішніх справ - Відділ безпеки, Служба наглядів, Бюро спорту й охорони дикої фауни, Бюро у справах індіанського населення.

У більшості органів поліції $є$ добре оснащені пошуковими та дослідницькими приладами криміналістичні лабораторії, сучасні засоби зв'язку та інформації, автотранспорт і спеціалізовані приміщення, тобто всі необхідні засоби й умови для ефективного використання досягнень природничих і технічних наук у процесі попередження, розк- 
риття та розслідування злочинів.

Не менш досконале техніко-криміналістичне забезпечення слідчої діяльності наявне у Федеральному бюро розслідування. У його структурі разом із такими відділами, як контррозвідувальний, іноземний, політичного розшуку, промислового, адміністративного навчання та інспекції, створені підрозділи, у діяльності яких постійно й активно використовують криміналістичні технічні засоби, прийоми й методи. До числа таких підрозділів належать відділи карного розслідування та впізнання особистості, або ідентифікації, а також лабораторії, що мають кілька спеціалізацій, включаючи криміналістичні [14].

У Сполученому Королівстві Великобританії та Північної Ірландії, тобто в Англії, так само, як і в Сполучених Штатах Америки, криміналістика, у ії розумінні російськими вченими, не визнана, але криміналістичне технічне забезпечення попередження, розкриття та розслідування злочинів широко й різнобічно розвинені. Найбільш активно вони проявляються в діяльності англійської поліції, яка має 52 самостійних підрозділи, кожен із яких очолює начальник поліції, за винятком графства Метрополітен і Лондона, де ними керують комісари поліції. У більшості поліцейських підрозділів є заступники начальника поліції, які відповідають за боротьбу зі злочинністю і яким підпорядковуються відділи з розслідування шахрайства, незаконного обігу наркотиків та інших видів злочинів. Дев'ять окружних відділів в Англії й Уельсі є спеціальними підрозділами, що складаються з досвідчених офіцерів-слідчих, їх діяльністю керує старший поліцейський офіцер, який одночасно є окружним координатором боротьби зі злочинністю. Контроль за діяльністю всіх спеціальних груп здійснює національний координатор.

Форми та зміст використання криміналістичних технічних засобів, прийомів і методів в Англії визначаються цілою низкою чинників, у тому числі особливостями організації розслідування злочинів, можливостями сучасної науки й техніки, а також сформованими традиціями в цій галузі.

Англійські вчені та практичні працівники правоохоронних органів зробили величезний внесок у розвиток криміналістичних технічних засобів, прийомів і методів виявлення й викриття осіб, які вчинили злочини, - за допомогою відкриттів у дактилоскопії, серології, токсикології, судової балістики, генної ідентифікації та інших галузях наукового знання.

Поряд із криміналістичним технічним забезпеченням боротьби зі злочинністю в Англії були спроби дослідження і проблем криміналістичної тактики та криміналістичної методики розслідування злочинів, але вони не завершилися створенням самостійної англійської криміналістики [15].

Аналогічне становище і у Франції, яка зусиллями А. Бертільйона (без практики Ежена Відока, діяльність якого можна віднести до питань оперативно-розшукової діяльності) створила наприкінці XIX ст. першу у світі наукову систему криміналістичних обліків та ідентифікації злочинців, де в наш час відсутні структуровані криміналістичні наукові знання.

Таким чином, можна зробити висновок, що в більшості країн далекого зарубіжжя для забезпечення боротьби зі злочинністю продовжує розвиватися особлива галузь знання, яку на межі XIX-XX ст. називали в одних країнах наукової поліцією, а в інших - поліцейською технікою.

Ці знання мають виключно прикладний зміст, не володіють загальною теорією, обгрунтованою системою й не спираються на науково розроблені принципи та закони розвитку. Вони об'єднані своїм призначенням запозичувати й пристосовувати новітні досягнення природничих і технічних наук для вдосконалення виявлення та викриття злочинців.

На підставі проведеного дослідження можна сформулювати такі висновки:

1) характерною рисою розвитку зарубіжної криміналістики є майже повна відсутність робіт, присвячених дослідженню ії методологічних і теоретичних основ. Унаслідок цього і зараз у більшості країн Європи криміналістику не визнають самостійною наукою, а розглядають як допоміжну, суто прикладну дисципліну або взагалі як «поліцейську техніку», позбавлену правової регламентації. Тому коло проблем криміналістики обмежується комплексом спеціальних технічних засобів і прийомів, їй відводиться роль дисципліни, покликаної розробляти суто технічні рекомендації щодо розкриття та розслідування злочинів. I, як наслідок такого підходу, у ряді країн (зокрема у США) криміналістику викладають далеко не у всіх юридичних вищих навчальних закладах;

2) курси зарубіжної криміналістики зазвичай складаються $з$ чотирьох розділів: 
а) техніка вчинення злочинів; б) криміналістична техніка; в) криміналістична тактика; д) організація боротьби зі злочинністю;

3) питання організації боротьби зі злочинністю зазвичай складається 3 двох частин: у першій висвітлюють внутрішньодержавні, а в другій міжнародні форми й методи кримінального переслідування;

4) зростання злочинності, шо спостерігається практично повсюдно, змушує держави до пошуку більш ефективних заходів боротьби з нею;

5) зібрану інформацію піддають електронній обробці та вносять у бази даних комп'ютерних мереж, які обслуговують правоохоронні органи;

6) непогано розвинена й так звана польова криміналістика, тобто криміналістичні засоби й методи для застосування в ході огляду місця події, обшуку, затримання, огляду та інших слідчих і розшукових дій, які проводять у складних, а часто і несприятливих умовах. Поліція США, Німеччини, Англії, Франції, Японії має спеціально обладнані автомобілі та вертольоти, широко використовує в роботі телебачення, комп'ютерну й лазерну техніку. Поліцейські органи активно застосовують портативні прилади й датчики для попереднього експрес-аналізу крові, наркотичних і вибухових речовин, пошуку дорогоцінних металів, трупів. Вони зручні й результативні в застосуванні. Велику увагу приділяють розробці ефективних наборів засобів для роботи з різними слідами й мікрооб'єктами, а також для особистого захисту та безпеки співробітників поліції під час затримання озброєних злочинців;

7) у повсякденній діяльності поліція використовує новітні досягнення науковотехнічного прогресу, зокрема засоби мікроаналізу, голографії, комп'ютерних технологій. Електроніка широко представлена також у криміналістичній фотографії - це автоматичні камери, що забезпечують точне наведення на різкість, установку витримки та діафрагми навіть під час зйомок у складних умовах; мікропроцесори, якими оснащені фотозбільшувачі, що регулюють автоматичний підбір світлофільтрів у разі друкування кольорових знімків, та ін. У більшості розвинених капіталістичних держав поліція вже давно використовує тільки кольорові фотоматеріали, фотоапарати, що виключають процес фотодруку, цифрові камери, що знімають на знімні носії інформації. Зняті кадри можна відразу ж переглянути на екрані монітора, вивести на друк через принтер комп’ютера, передати по телекомунікаційних каналах. Давно поширений кольоровий відеозапис, у тому числі цифровий;

8) усе більше вдосконалюють криміналістичні засоби запобігання злочинних посягань: різні системи контролю й допуску, що виключають недозволене проникнення на об'єкт, який перебуває під охороною, пронесення зброї, вибухівки, наркотиків, дорогоцінних металів, товарів, забезпечених спеціальними бирками, і под. Активно застосовують портативні детектори фальшивих грошей і цінних паперів, системи, що стежать і реєструють, у банках, супермаркетах та інших закладах, де зосереджуються великі суми грошей та цінні товари;

9) велику увагу приділяють розробці й використанню аналітичних засобів під час допитів, особливо таких пристроїв, як поліграф, варіограф (просторе моделювання), детектор приховуваного знання тощо. Прилади типу поліграф уже багато років застосовують у практиці боротьби зі злочинністю понад 20 держав, у тому числі США, Швейцарія, Японія, Туреччина та ін. Там створені спеціальні лабораторії, які обслуговують кваліфіковані фахівці. Деякі сучасні конструкції поліграфів безконтактно реєструють десятки різних психофізіологічних параметрів, динаміку яких аналізує вбудований комп'ютер за спеціальною програмою. Точність діагностики причетності осіб, підозрюваних у вчиненні злочинів, забезпечується в межах 75-100\%.

Із певною часткою ймовірності можна прогнозувати, що в умовах подальшого поширення й затвердження вітчизняної криміналістики у світі буде зростати затребуваність і збільшуватися значення в боротьбі зі злочинністю всіх ії основних розділів криміналістичної техніки, криміналістичної тактики та криміналістичної методики розслідування окремих видів злочинів.

\section{Список використаних джерел}

1. Криміналістика: підручник / П. Д. Біленчук, В. К. Лисиченко, Н. І. Клименко; за ред. П. Д. Біленчука. 2-ге вид., випр. і доп. Київ: Атіка, 2001. 544 с.

2. Комаха В. О. Ганс Гросс - один із піонерів і «батько» світової криміналістики. Юридические записки. 2014. № 1. С. 111-117.

3. ForensicSCienceHistory.URL:https//www.troopers.ny.gov/Crime_Laboratory_System/History/Forensic_Science_History/. 
4. Eichberg F. Anleitung zum Vergleichen von Fingerabdrucken. Wien, Manz. 1915.

5. Jagemann H. F. Handbuch der gerichtlichen Untersuchungskunde. Frankfurt-a-Main: Verlag Rettembeil, 1838. $772 \mathrm{~s}$.

6. Heindl R. Sistem und Praxis der Daktyloskopie und der sonstigen technischen Methoden der Kriminalpolizei. Berlin und Leipzig, $1929 . \quad 655$ s.. $\quad$ URL: https://books.google.com.ua/books/about/System_und_Praxis_der_Daktyloskopie_und.html?id=iuBWAA AAYAAJ\&redir $\mathrm{esc}=\mathrm{y}$.

7. Kriminalistische Spurensicherung: Sammlung dienstlicher Anweisungen und sachverständiger Ratschläge für den Dienstgebrauch und für Polizeischulen, als Hrsg. Berlin, 1944.

8. Kobe $£$, Schurich F.-R. Die Kriminalistik in Deutschland. Hamburg, 1964. 79 s.

9. Майер Х., Вольф К., Чекалла Ю. Учебник криминалистики для полиции. ФРГ, 1983.

10. Постика И. В. Основные проблемы криминалистической науки, раскрытия и расследования преступлений в восточноевропейских странах. URL: https://crimcongress.com/portretnaya/postika-igor-vladimirovich/.

11. Kriminalistische Kompetenz. Chefredktion: Rolf Reiner Jaeger. Verlag: Schmidt-Romhild, Lubeck-Deutschland, 2000.

12. Clages H. Kriminalistik. Lehrbuch fur Ausbildung und Praxis. Stuttgart, 1994. $251 \mathrm{~s}$

13. Smith D. N. The Law of Confessions and Scientific evidence. North Carolina, 1963. 308 p.

14. Falcone D. N., Charles M. T. and Wells E. A. Study of Pursuits in Illinois. The Police Chief, 1994, July. P. 59-64.

15. Bonger W. A. An Introduction to Criminilogy. London, 1936. 128 p.

Надійшла до редакиії 30.04.2020

\section{References}

1. Kryminalistyka [Forensics]: pidruchnyk / P. D. Bilenchuk, V. K. Lysychenko, N. I. Klymenko; za red. P. D. Bilenchuka. 2-he vyd., vypr. i dop. Kyyiv: Atika, 2001. 544 s. [in Ukr.]

2. Komakha, V. O. (2014) Hans Hross - odyn iz pioneriv i «bat'ko» svitovoyi kryminalistyky [Hans Gross - one of the pioneers and "father" of world forensics]. Yuridicheskiye zapiski. № 1. S. 111117. [in Ukr.]

3. Forensic

Science

History.

URL:

https://www.troopers.ny.gov/Crime_Laboratory_System/History/Forensic_Science_History/.

4. Eichberg F. Anleitung zum Vergleichen von Fingerabdrucken [Instructions for comparing fingerprints]. Wien, Manz. 1915. [in Ger.]

5. Jagemann H. F. Handbuch der gerichtlichen Untersuchungskunde [Handbook of forensic investigators]. Frankfurt-a-Main: Verlag Rettembeil, 1838. 772 s. [in Ger.]

6. Heindl R. System und Praxis der Daktyloskopie und der sonstigen technischen Methoden der Kriminalpolizei [System and practice of dactyloscopy and other technical methods of the criminal police]. Berlin und Leipzig, $1929 . \quad 655 \mathrm{~s} . \quad$ URL: https://books.google.com.ua/books/about/System_und_Praxis_der_Daktyloskopie_und.html?id=iuBWAA AAYAAJ\&redir esc=y. [in Ger.]

7. Kriminalistische Spurensicherung: Sammlung dienstlicher Anweisungen und sachverständiger Ratschläge für den Dienstgebrauch und für Polizeischulen 「Criminal Forensics: Collection of official instructions and expert advice for official use and for police schools], als Hrsg. Berlin, 1944. [in Ger.]

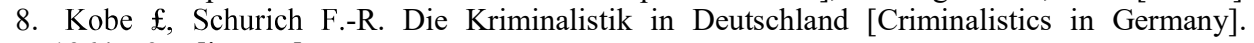
Hamburg, 1964. 79 s. [in Ger.]

9. Mayyer, X., Vol'f, K., Chekalla, Yu. Uchebnik kriminalistiki dlya politsii [Textbook of Forencisc for police]. FRG, 1983. [in Russ.]

10. Postika, I. V. Osnovnyye problemy kriminalisticheskoy nauki, raskrytiya i rassledo-vaniya prestupleniy v vostochnoyevropeyskikh stranakh [The main problems of forensic science, the disclosure and investigation of crimes in Eastern European countries]. URL: https://crimcongress.com/portretnaya/postika-igor-vladimirovich/. [in Russ]

11. Kriminalistische Kompetenz [Forensic competence]. Chefredktion: Rolf Reiner Jaeger. Verlag: Schmidt-Romhild, Lubeck-Deutschland, 2000. [in Ger.]

12. Clages H. Kriminalistik. Lehrbuch fur Ausbildung und Praxis [Criminalistics. Textbook for training and practice]. Stuttgart, 1994. 251 s. [in Ger.]

13. Smith D. N. The Law of Confessions and Scientific evidence. North Carolina, 1963. 308 p.

14. Falcone D. N., Charles M. T. and Wells E. A. Study of Pursuits in Illinois. The Police Chief, 1994, July. P. 59-64.

15. Bonger W. A. An Introduction to Criminilogy. London, 1936. 128 p.

\section{SUMMARY}

Oleksandr S. Sainchin. Theory and History Development of Criminal Investigations abroad. In the conditions of formation and development of new socio-economic relations, reformation of legislative state structures, executive and judicial power, the task of creating a legal basis for law strengthening and the law enforcement activity improving arises. The legal sciences should develop and form the statehood and lawfulness legal basis of law-enforcement activity, aimed to reliable protection of constitutional rights and legitimate interests of citizens, public formations and state structures of Ukraine.

Criminalistics equips law enforcement officers with effective methods and means of detecting and investigating crimes, which promotes the principle of the inevitability of punishment, the objective use of 
criminal law and preventive influence.

Recently, Ukraine has been paying special attention to the law enforcement agencies activities improving and strengthening the scientific and technical base for combating crime in general, and organized in particular. The current level of criminalistics science and the scientific and technical potential of the natural and technical sciences, allowing prosecutors, internal affairs, security and court authorities to prevent, suspend and investigate very complex crimes, thereby contributing to the solution of one of the main tasks - strengthening law and order in Ukraine .

Criminalistics science is a legal science that has emerged in the criminal process depths in the last century as a set of technical means and tactical techniques, as well as ways of using them for disclosure and investigation. The article further investigates the problems of criminalistics theory and history in some countries of Europe, USA, and England. The overall purpose of this analysis is to investigate how the development of criminalistics outside our country, their problems, and most importantly, to reach a conclusion about the need for restructuring (or sufficiency) of criminalistics methods and expert research system.

The study deals exclusively with the theory and history of scientific knowledge development in criminalistics outside our country, to identify the positive features of its modern development and extrapolation to the conditions of our science, which serves as a specific tool in investigating crimes and identifying the perpetrators. In the next study, it is planned to offer a discussion among scholars and practitioners involved in crime investigations about the contemporary achievements possible implementation of our criminalistics colleagues abroad.

Keywords: criminalistics, history of criminalistics, criminalistics abroad, criminalistics science in some countries of Europe, USA and England, criminalistics as a science and applied field of law.

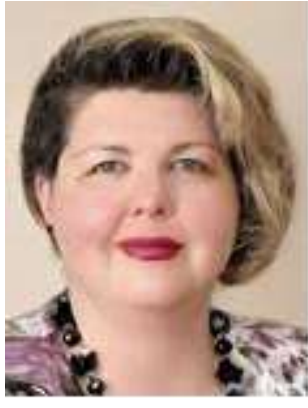

Наталія ФІЛІПЕНКО

кандидат юридичних наук, доцент (Наиіональний аерокосмічний університет ім. М. С. Жуковського «Харківський авіаиійний інститут»)

\section{Олександр СНІГЕРЬОВ} доктор юридичних наук, професор (Харківський НДІ судових експертиз ім. Засл. проф. M. С. Бокаріуса)

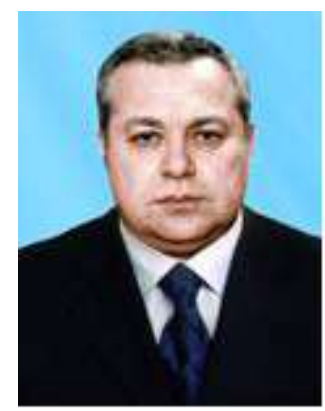

\title{
ЕКСПЕРТНА ПРЕВЕНЦІЯ: ПОНЯТТЯ, ПРЕДМЕТ ТА ОБ'ЄКТ
}

Проаналізовано концептуальні засади, погляди та ідеї шодо розуміння сутності приватної теорії судової експертизи - експертної превенції, розглянуто ії поняття. Досліджено емпіричні передумови виникнення й розвитку судової експертизи, як сукупність емпіричних фактів у теорії судової експертизи та інших науках, прояви інтеграційних процесів. Сформульовано теоретичні й прикладні основи приватної теорії експертної превенції. Розглянуто й проаналізовано ії поняття, структуру, предмет, об'єкт та завдання. 3'ясовано ії місце та роль у теорії криміналістики й судової експертизи.

На думку авторів, предметом приватної теорії експертної превенції є теоретичні, нормативно-правові та організаційні закономірності здійснення превентивної діяльності; закономірності виникнення та формування підстав превентивної діяльності на основі єдиної методології, уніфікованого понятійного апарату; перебудова та налаштування теоретичних категорій з урахуванням постійного оновлення, модернізації та видозміни спеціальних експертних знань; нормативноправове та організаційне забезпечення превентивної експертної діяльності; єдина мова наукової термінології та уніфікація превентивних стандартів тощо.

Ключові слова: криміналістика, судова експертиза, експертна превенція, загальна теорія судової експертизи, приватна теорія експертної превенції, спеціальні знання, судово-експертні установи.

\author{
(C) Філіпенко Н.С., 2020 \\ ORCID iD: https://orcid.org/0000-0001-9469-3650 \\ filipenko_natalia@ukr.net \\ (C) Снігерьов О.П., 2020 \\ sir2009@ukr.net
}

